\title{
NATIONAL KEY ECONOMIC AREA MULTIPLIER IMPACT ON MALAYSIAN ECONOMY: AN INPUT-OUTPUT ANALYSIS
}

\author{
SITI NADIAH AHMAD FUAD \\ AHMAD FAUZI PUASA \\ Malaysian Institute of Economic Research
}

\begin{abstract}
The ultimate aim of this research is to provide an analysis of the impact multipliers on the Malaysian economy for 12 NKEA sectors. Economic activity is a complicated web of interdependent behaviour. A change in any part of the economy leads to changes elsewhere. Consequently, the estimation of the ultimate total impact of a change in the NKEA requires the measurement of the changes that occur elsewhere in the economy. The technique available to obtain these measurements is called input-output (I-O) analysis. I-O analysis is concerned with studying the interdependence of the producing and the consuming units in the modern economy. Our computation of complete I-O multipliers includes total output, income, employment, value-added, imported commodity, domestic taxes and imported taxes multipliers for the NKEA. Among the NKEA sectors, the palm oil, tourism, education, healthcare and other sectors have great potential for further development and are expected to give a high impact on the Malaysian economy. If the government wishes to boost the Malaysian economy for growth, these are the appropriate sectors for development.
\end{abstract}

Keywords: NKEA, input-output analysis, multiplier impact.

\section{Introduction}

A new approach has been taken to develop the Economic Transformation Programme (ETP). It is the first time that any effort of this kind has been undertaken in the history of Malaysia, or of any other developed nation. The programme provides strong focus on a few key growth engines: the 12 National Key Economic Areas (NKEAs). These NKEAs are expected to make substantial contributions to Malaysia's economic performance, and they will receive prioritized public investment and policy support. 
NKEA is defined as a driver of economic activity that has the potential to directly and materially contribute a quantifiable amount of economic growth to the Malaysian economy. The NKEAs were selected because they are significant engines of future growth and their expected contribution to GNI in 2020 will help Malaysia achieve high income status. This paper presents an input-output model to estimate the impact of NKEAs on the Malaysian economy.

Economic activity is a complicated web of interdependent behaviour. A change in any part of the economy leads to changes elsewhere. Consequently, estimation of the ultimate total impact of a change in the NKEAs requires the measurement of the changes that occur elsewhere in the economy.

One technique available to obtain these measurements is called the input-output (I-O) analysis. The I-O analysis is concerned with studying the interdependence of the producing and the consuming units in a modern economy. The main concern of this study is to show the interrelations among the different subsectors, within the agriculture sector, which purchase goods and services from other subsectors, and which in turn produce goods and services and sell them to other subsectors. The interrelationship between the different subsectors is the strength of the I-O analysis. Normally, the various economic flows are set out in an I-O table, which is specially designed to provide a concise and systematic arrangement of all economic activities within a state or region. The procedures of computing an I-O analysis are based on matrix algebra, but knowledge of this subject is not necessary for understanding how the system works. Lack of advanced mathematical knowledge is not the main difficulty in this field of enquiry. Assembling the basic data from various sources presents the main problem and takes a major part of the time involved in the operation. The final calculation, involving matrix inversion, can be done in a very short time and at a relatively small cost using the computer.

The application of the I-O system has been widely used in economic analysis and new forms of both theory and applications have constantly been tried out and developed. New ideas and applications are usually offered for discussions at World Input-Output Conferences organized at three-yearly intervals by Leontief and his associates of the Harvard Economic Research Project.

The concept of multipliers explains how much the economy will increase or decrease because of a change in the final demand. Multipliers are simply the sum of direct effects, indirect effects and 
induced effects. The relationship between the initial spending and the total effects generated by the spending is known as the multiplier effect of the subsector, or more generally, as the impact of the subsector on the economy as a whole. Differences between direct, indirect, induced and total multiplier effects are of economic significance. The differences between the multipliers are analogous to those between output, income and employment (Aruna et al., 1997). Direct effects are often the largest, followed by the induced and the indirect effects. The smaller magnitude of the indirect effect is the result of a lack of inter-industry purchases and the resulting need to import a large percentage of the supporting goods and services.

\section{Literature Review}

Several studies have applied the input-output model to analyse regional economies. Examples for these are Beyars (1974), Oksanen and Williams (1984), Stull and Madden (1990), Hefner and Guimaraes (1994), Hughes and Holland (1994) and Vander-Schaff (1995). In his study of the Puget Sound region in Washington D.C. State, Beyars (1974), found high output multipliers among financial, business, and engineering/research/management services. Stull and Madden's (1990) study of the Philadelphia metropolitan area revealed high output multipliers for educational sciences, financial and health services, and tourism. Thus, for Philadelphia and Puget Sound, a producer services cluster drives economic growth and development.

According to Turgut and Jojo (1985), on The Multiplier Impact of Tourism in the Okanagan, the primary objective of this study is to examine the economic impact of tourism on the Okanagan Region, (B.C., Canada), by evaluating the multiplier effects of tourist expenditure on the generation of income, sales and employment. Specifically, separate multipliers are calculated in order to identify the relative contribution of four major types of tourists, namely: (a) Nonresidential visitors, (b) residential visitors (B.C.), (c) day-trippers, and for the first time, (d) convention delegates. This study utilizes the Archer tourism multiplier methodology by adopting a price level adjusted to the twenty-nine sector input-output framework as the basis for calculating the tourist multipliers.

In a subsequent study on the Input-Output Analysis on the $\mathrm{CO} 2$ emission in the housing industry by Fujita, Ho and Matsumoto (2007), Environmental Life Cycle Assessment Using Input-Output Techniques was used to make a preliminary assessment of $\mathrm{CO} 2$ emission in the housing industry in Malaysia. This study used data 
from the National Census and the National Balance of Energy (PTM, 2000) to compute CO2 emission by fuel type in direct and indirect energy consumption.

Other investigators have applied input-output models to determine the impacts of specific companies on regional economy. For example, Erickson (1974) analysed the impact of Boeing on the Washington State economy. Warf (1996) examined the impact of the engineering services industry on the national economy. Russel (1998) calculated the impact of the aviation industry on the Wisconsin economy and Charney and Leones (1995) measured the impact of high technology cluster on the Arizona economy.

In another study, Thomson and Psaltopoulos (1993) investigated the role of the forestry sector in rural development using the inputoutput model developed by Jenson and West (1986), known as the Generating Regional Input-Output Tables or GRIT. The findings from the study suggested that the rural multiplier effects arising from both the forest planting and forest harvesting sectors were relatively small due to the dependence of rural firms on goods, services and labour from non-rural areas. The study emphasized the importance of the calculation of a multiplier, which included induced effects, in order to get a better understanding of the contribution of the sector.

In Ohio, USA, a study was carried out by Kriesel (1996) on the economic impact of outdoor recreation at the Wayne National Park using the input-output analysis. The emphasis of this study was on the economic impact of expenditures by visitors on the recreational opportunities in the National Park. The study showed that in 1996 the Park received about 689,000 visitors, of whom approximately 384,000 were from outside the local impact area. The visitors spent US\$82.84 per person during their visits, which increased the total economic impact to US $\$ 45.7$ million resulting in a total income effect of US\$24.9 million and created 1024 jobs. This indicated that recreation services were important to the Ohio economy.

\section{Methodology}

The input-output analysis is a basic method of quantitative economics that portrays macroeconomic activity as a system of interrelated goods and services. An increase in the output of one sector increases the demand for output in its supplying industries. There are two commonly used versions of the input-output (I-O) model, called the 
open-closed model. Both the Open and the Closed I-O models capture only the direct and indirect effects. The closed version incorporates the household sector into the first quadrant of the common I-O table by treating household income and expenditure as endogenously determined. The model allows for getting the induced effects, as well as the direct and indirect effects (Miller Blair, 1985). In this analysis, the closed I-O model with respect to the household is used.

Every $£ 1$ final demand for the products of a sector generates indirect as well as direct income effects on the economy as a whole. The relationship between the initial spending and the total effects generated by the spending is known as the multiplier effect of the sector, or more generally as the impact of the sector on the economy as a whole. For this reason the study of multipliers has come to be called impact analysis. Before taking up this study however, it is useful to refer briefly to some theoretical ideas on which the subject is based.

\section{Keynesian Concepts}

Though the original multiplier idea can be traced back to Kahn's work in 1931 the modern concept of an income multiplier is usually associated with J.M. Keynes and might be described as follows. A unit increment of 'autonomous' investment causes an initial increase in income which generates successive rounds of consumer spending and incomes, each round producing numerically smaller increments until the process has fully worked itself out, i.e. has reached equilibrium. The fully worked-out response to the stimulus produces:

Savings equal to the initial unit increment of investment, and consumer spending (household consumption) considerably larger than the initial unit increment of investment.

The household consumption is a multiple of the unit increment of investment, the multiplier being given by

$$
\frac{1}{1-c}
$$

where $\mathrm{c}=$ the marginal propensity to consume

Other assumed autonomous expenditures like government spending and exports have a similar effect.

The above explanation gives an over-simplified picture of reality and an exaggerated estimate of the multiplier, because both government 
taxation and purchase of imports reduce the size of the multiplier, so that the latter is considerably smaller than $\frac{1}{1-c}$, in normal presentday economic conditions. What has been made clear, however, is the principle of household consumption interacting with household income through successive rounds, so as to produce an increment of household consumption larger than the initial unit of autonomous investment, at the equilibrium level.

\section{Multiplier Impacts}

Multiplier coefficients represent the ability of any given sector or subsector to generate output, income, employment and any other multipliers from any given change in the demand for its output. The multiplier values can be used to show the impacts on the national economy as a result of a given change in any of its final demands. These impacts can be subdivided into three categories:

\section{Direct Effects}

Direct effects are those brought about, directly in those subsectors that are subjected to the change in the final demand. Therefore, a change in the level of activity of the wood products industry will directly be felt by those manufacturing industries that are involved in the production of those products.

\section{Indirect Effects}

When there is a change in the final demand for a subsector's output, the subsector will have input demands of its own. For instance, the electrical machinery industry may need to purchase additional transport services, other financial services from industries within their own sector and supporting services related to, say, energy services.

\section{Induced Effects}

Whenever a good or service is produced, some income is accrued as wage, salary, profit, rent or interest (or some combination of these). Therefore, in the direct and indirect effects income is accrued as a result of the initial change in the final demand. When that income is re-spent, it triggers another round of economic activity. This additional round of economic activity generates output, income and employment and other multipliers. The economic effects that result 
from the re-spending of accrued incomes are known as the induced effects. The multiplier ratios allow the determination of the effects resulting from any change in the final demand. Depending upon the multiplier, these full effects may be the direct plus indirect effects, or the direct plus indirect plus induced effects.

\section{Source of Data}

The raw data was extracted from the Input-Output Table 2005, Department of Statistics, Malaysia. These national data consist of 120 sectors. All these data were aggregated to 12 sectors according to NKEAs that were selected based on their expected contribution to GNI in 2020. In addition to the 11 industry sectors, Greater Kuala Lumpur/Klang Valley was selected as an NKEA through a separate process. Kuala Lumpur currently accounts for about one third of Malaysia's GDP and thriving Kuala Lumpur is vitally important to the health and performance of the overall economy.

\section{Analysis and Results}

The Malaysian I-O Table 2005 was used in this analysis, whereby the employee and wages were used as endogenous variables, together with private consumption in the corresponding column. Based on the technical and interdependent intermediate coefficient information for the I-O system, the total output, income, and other multipliers were calculated for 12 sectors.

The results of the study for every multiplier were discussed as below.

\section{Output Multiplier}

The output multiplier for every sector is expressed as the ratio of direct, indirect and induced output changes to the direct output change due to a unit increase in the final demand. So multiplying a change in the final demand (direct impact) for an individual sector's output by that sector's (direct and indirect) output multiplier will generate an estimate of the direct plus indirect impacts upon output throughout the Malaysian economy.

The results from the analysis were sorted into 12 NKEA sectors for easier further analyses of the Malaysian economy (see Table 1). The total output multiplier ranges from 1.865 to 3.113 . The flow-on 
effect on output multiplier ranges from 0.865 to 2.113 . This was the result of an increase of one Ringgit in the final demand. It shows that the increases in household income in the NKEA sectors are quite substantial in the Malaysian economy.

Palm oil has the highest output multiplier among the NKEAs sectors, followed by tourism, and financial services. The lowest output multiplier is electronics and electrical sector. There are eight sectors of total output multipliers that are greater than two which implies that these sectors are able to generate output more than one as a result of every Ringgit increase in the final demand.

The palm oil sector possesses a high first round effect and an industrial effect, but the consumption-induced effect has only a moderate effect level. A high induced industrial multiplier creates a good economic activity for that sector and ultimately gives rise to a good economic growth.

In general, there are eight sectors in the NKEAs which are capable of generating high total output multipliers. The sectors are palm oil, tourism, financial services, healthcare, education, communication content and infrastructure, greater KL/Klang, and agriculture. The government should put more weight to these sectors for development, which would increase the total Malaysian output. Those sectors with low total output multipliers, deserve less emphasis for development, but we cannot ignore them.

Table 1

Output Multiplier

\begin{tabular}{|c|c|c|c|c|c|c|c|c|}
\hline No. & Sector & $\begin{array}{l}\text { IO } \\
\text { Code }\end{array}$ & $\begin{array}{l}\text { Initial } \\
\text { Effect } \\
(1)\end{array}$ & $\begin{array}{c}\text { First } \\
\text { Round } \\
\text { (Direct) } \\
(2)\end{array}$ & $\begin{array}{c}\text { Industrial } \\
\text { Support } \\
\text { (Indirect) } \\
\text { (3) }\end{array}$ & $\begin{array}{l}\text { Consumption } \\
\text {-Induced } \\
\text { (4) }\end{array}$ & $\begin{array}{l}\text { Total Multiplier } \\
\begin{array}{c}(1)+(2)+(3)+(4) \\
=(5)\end{array}\end{array}$ & $\begin{array}{l}\text { Flow-on } \\
\text { (5)-(1) } \\
=(6)\end{array}$ \\
\hline 1 & Palm Oil & 7 & 1 & 0.657 & 0.936 & 0.520 & 3.113 & 2.113 \\
\hline 2 & Tourism & 3 & 1 & 0.625 & 0.648 & 0.657 & 2.931 & 1.931 \\
\hline 3 & $\begin{array}{l}\text { Financial } \\
\text { Services }\end{array}$ & 11 & 1 & 0.524 & 0.512 & 0.650 & 2.686 & 1.686 \\
\hline 4 & Healthcare & 6 & 1 & 0.508 & 0.456 & 0.443 & 2.408 & 1.408 \\
\hline 5 & Education & 2 & 1 & 0.287 & 0.244 & 0.859 & 2.390 & 1.390 \\
\hline
\end{tabular}

(continued) 


\begin{tabular}{|c|c|c|c|c|c|c|c|c|}
\hline No. & Sector & $\begin{array}{c}\mathrm{IO} \\
\text { Code }\end{array}$ & $\begin{array}{l}\text { Initial } \\
\text { Effect } \\
(1)\end{array}$ & $\begin{array}{c}\text { First } \\
\text { Round } \\
\text { (Direct) } \\
\text { (2) }\end{array}$ & $\begin{array}{c}\text { Industrial } \\
\text { Support } \\
\text { (Indirect) } \\
\text { (3) }\end{array}$ & $\begin{array}{c}\text { Consumption } \\
\text {-Induced } \\
(4)\end{array}$ & $\begin{array}{l}\text { Total Multiplier } \\
\begin{array}{c}(1)+(2)+(3)+(4) \\
=(5)\end{array}\end{array}$ & $\begin{array}{l}\text { Flow-on } \\
\begin{array}{c}(5)-(1) \\
=(6)\end{array}\end{array}$ \\
\hline 6 & $\begin{array}{l}\text { Communication } \\
\text { Content and } \\
\text { Infrastructure }\end{array}$ & 8 & 1 & 0.447 & 0.420 & 0.328 & 2.195 & 1.195 \\
\hline 7 & Others & 12 & 1 & 0.472 & 0.417 & 0.304 & 2.193 & 1.193 \\
\hline 8 & Agriculture & 9 & 1 & 0.363 & 0.282 & 0.419 & 2.064 & 1.064 \\
\hline 9 & $\begin{array}{l}\text { Oil, Gas and } \\
\text { Energy }\end{array}$ & 1 & 1 & 0.437 & 0.349 & 0.128 & 1.915 & 0.915 \\
\hline 10 & $\begin{array}{l}\text { Business } \\
\text { Services }\end{array}$ & 10 & 1 & 0.330 & 0.290 & 0.292 & 1.912 & 0.912 \\
\hline 11 & $\begin{array}{l}\text { Wholesale and } \\
\text { Retail }\end{array}$ & 4 & 1 & 0.392 & 0.349 & 0.154 & 1.894 & 0.894 \\
\hline 12 & $\begin{array}{l}\text { Electronics and } \\
\text { Electrical }\end{array}$ & 5 & 1 & 0.398 & 0.309 & 0.159 & 1.865 & 0.865 \\
\hline
\end{tabular}

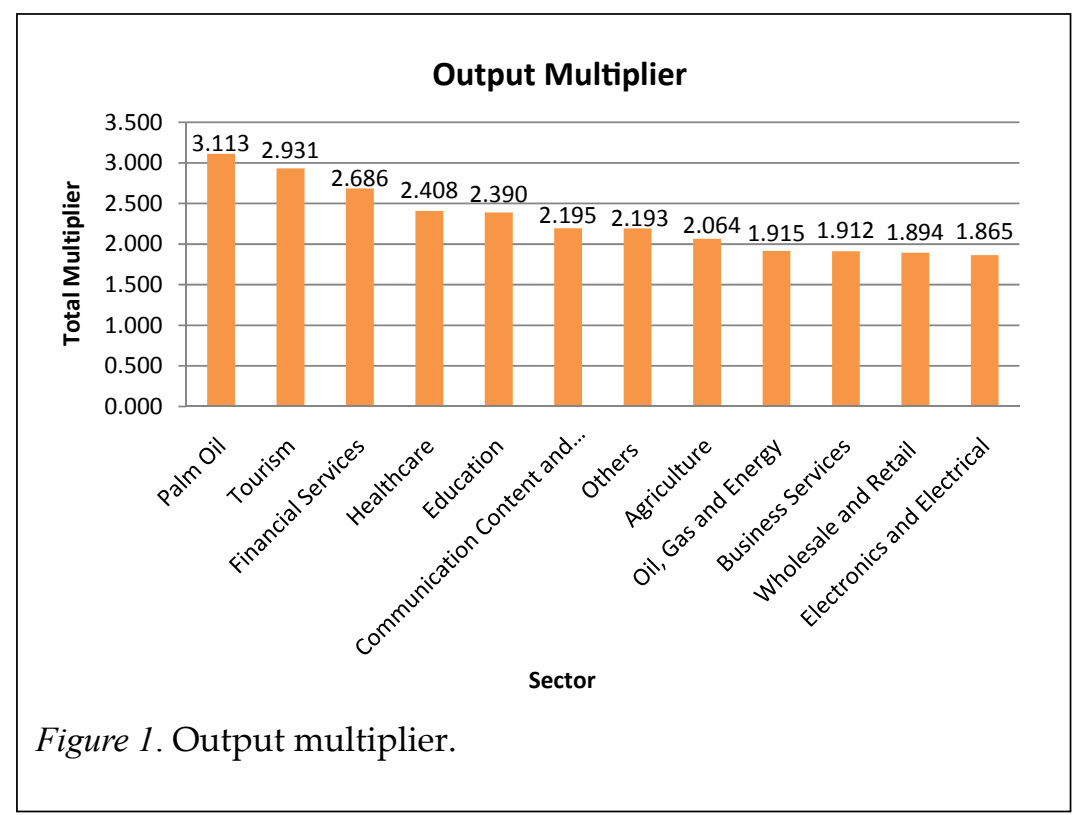

\section{Income Multiplier}

The income multiplier measures the change in income (compensation of employees) which occurs throughout the economy as a result of a change in the final demand. They show the ratio of direct, indirect plus induced income changes to the direct income change. 
The total income multiplier ranges from 0.087 to 0.584 . This shows that every one Ringgit increase in the final demand could increase the income multiplier for the NKEA sectors by 0.087 to 0.584 . This implies that the NKEA sectors are capable of generating household income of 0.087 to 0.584 cent for every Ringgit increase in the final demand. The flow-on effect on income multipliers ranges from 0.055 to 0.230 .

Based on Table 2, the education sector has the highest income multiplier, followed by the tourism and financial services. It is most likely that these sectors require high skill and knowledge for good quality high-end output in the competitive market. The lowest income multiplier is the oil, gas, and energy sector.

Table 2

Income Multiplier

\begin{tabular}{|c|c|c|c|c|c|c|c|c|}
\hline No. & Sector & $\begin{array}{l}\text { IO } \\
\text { Code }\end{array}$ & $\begin{array}{l}\text { Initial } \\
\text { Effect } \\
(1)\end{array}$ & $\begin{array}{l}\text { First } \\
\text { Round } \\
\text { (Direct) } \\
\text { (2) }\end{array}$ & $\begin{array}{c}\text { Industrial } \\
\text { Support } \\
\text { (Indirect) } \\
\text { (3) }\end{array}$ & $\begin{array}{c}\text { Consumption } \\
\text {-Induced } \\
(4)\end{array}$ & $\begin{array}{c}\text { Total } \\
\text { Multiplier } \\
\begin{array}{c}(1)+(2)+(3)+(4) \\
=(5)\end{array}\end{array}$ & $\begin{array}{l}\text { Flow-on } \\
\begin{array}{l}(5)-(1) \\
=(6)\end{array}\end{array}$ \\
\hline 1 & Education & 2 & 0.442 & 0.031 & 0.024 & 0.088 & 0.584 & 0.143 \\
\hline 2 & Tourism & 3 & 0.217 & 0.089 & 0.074 & 0.067 & 0.447 & 0.230 \\
\hline 3 & $\begin{array}{l}\text { Financial } \\
\text { Services }\end{array}$ & 11 & 0.215 & 0.089 & 0.071 & 0.067 & 0.442 & 0.227 \\
\hline 4 & Palm Oil & 7 & 0.123 & 0.075 & 0.102 & 0.053 & 0.353 & 0.230 \\
\hline 5 & Healthcare & 6 & 0.156 & 0.055 & 0.045 & 0.045 & 0.302 & 0.145 \\
\hline 6 & Agriculture & 9 & 0.172 & 0.042 & 0.028 & 0.043 & 0.285 & 0.113 \\
\hline 7 & $\begin{array}{l}\text { Communication } \\
\text { Content and } \\
\text { Infrastructure }\end{array}$ & 8 & 0.069 & 0.065 & 0.055 & 0.034 & 0.223 & 0.154 \\
\hline 8 & Others & 12 & 0.092 & 0.043 & 0.041 & 0.031 & 0.207 & 0.115 \\
\hline 9 & $\begin{array}{l}\text { Business } \\
\text { Services }\end{array}$ & 10 & 0.106 & 0.033 & 0.029 & 0.030 & 0.199 & 0.093 \\
\hline 10 & $\begin{array}{l}\text { Electronics and } \\
\text { Electrical }\end{array}$ & 5 & 0.045 & 0.021 & 0.026 & 0.016 & 0.108 & 0.063 \\
\hline 11 & $\begin{array}{l}\text { Wholesale and } \\
\text { Retail }\end{array}$ & 4 & 0.025 & 0.031 & 0.033 & 0.016 & 0.104 & 0.080 \\
\hline 12 & $\begin{array}{l}\text { Oil, Gas and } \\
\text { Energy }\end{array}$ & 1 & 0.032 & 0.018 & 0.024 & 0.013 & 0.087 & 0.055 \\
\hline
\end{tabular}




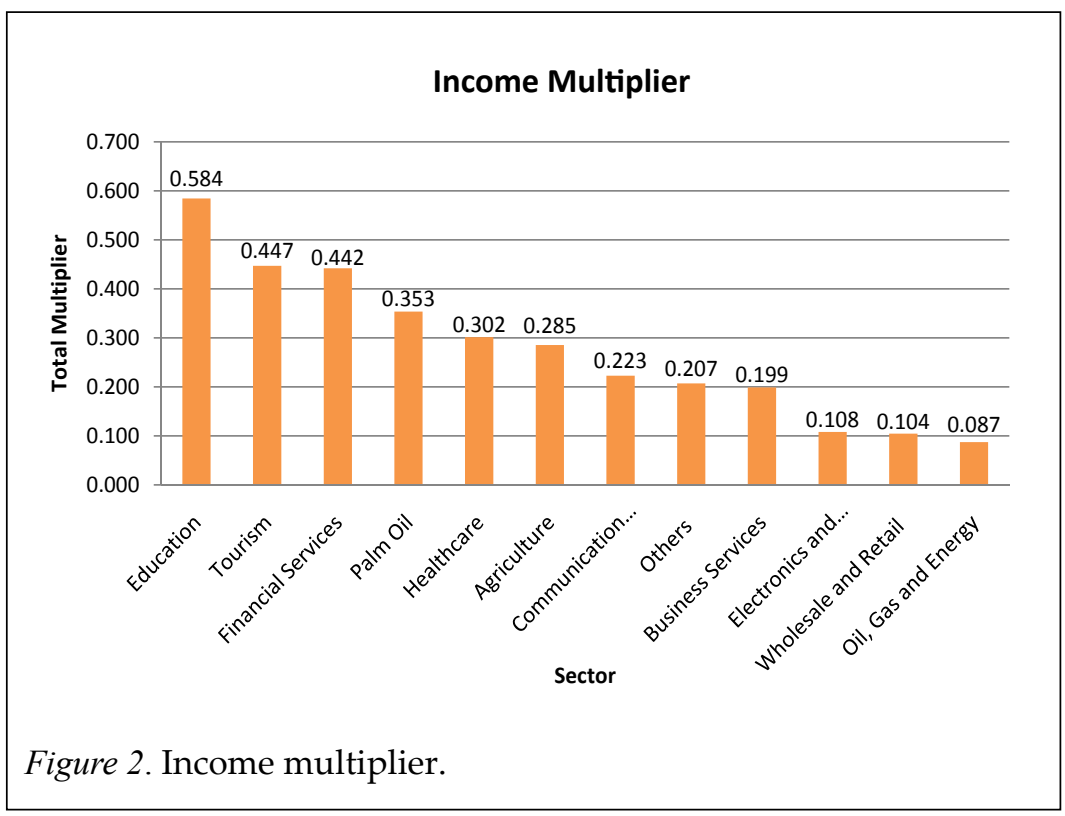

\section{Employment Multiplier}

Theemployment multiplier is the ratio of the direct and the indirect plus the induced employment changes to the direct employment change. With the increase in the final demand, production scale expands correspondingly while expanding scale, in turn, drives the demand of the national economy for labour force, which produces multiplier effects (Cuihong, 2000).

Table 3 shows that the agriculture sector has the largest employment multiplier followed by the education and the healthcare sectors. Therefore, these sectors are labour intensive, thus the employment multipliers are considerably high. The lowest employment multiplier is oil, gas and energy followed by electronic and electrical. These sectors normally use high technology. Therefore, the employment multiplier is usually small.

The total employment multiplier ranges from 0.004 to 0.048 per 1000 of output as a result of an increase of one Ringgit in the final demand, while the flow-on multiplier ranges from 0.004 to 0.016 per 1000 of output. This means that the agriculture, education and healthcare have greater impacts in terms of employment if these sectors' final demands change. 
The agriculture sector can also generate employment of 0.048 person for every 1000 total output created in the NKEA sectors. It is expected to create employment opportunities in the Malaysian economy with every one Ringgit increase in the final demand. The employment multiplier can be used to determine the relative effectiveness of the sectors to promote area growth and provide information in identifying the economic development for the different sectors. Creating employment means generating household incomes in the Malaysian economy. These household incomes will generate economic activities when the incomes are spent on food and other basic needs for the households.

Table 3

Employment Multiplier

\begin{tabular}{|c|c|c|c|c|c|c|c|c|}
\hline No. & Sector & $\begin{array}{l}\text { IO } \\
\text { Code }\end{array}$ & $\begin{array}{c}\text { Initial } \\
\text { Effect } \\
(1)\end{array}$ & $\begin{array}{c}\text { First } \\
\text { Round } \\
\text { (Direct) } \\
\text { (2) }\end{array}$ & $\begin{array}{l}\text { Industrial } \\
\text { Support } \\
\text { (Indirect) } \\
(3)\end{array}$ & $\begin{array}{l}\text { Consumption } \\
\text {-Induced } \\
(4)\end{array}$ & $\begin{array}{c}\text { Total } \\
\text { Multiplier } \\
(1)+(2)+(3)+(4) \\
=(5)\end{array}$ & $\begin{array}{l}\text { Flow- } \\
\text { on } \\
(5)-(1) \\
=(6)\end{array}$ \\
\hline 1 & Agriculture & 9 & 0.035 & 0.007 & 0.003 & 0.003 & 0.048 & 0.012 \\
\hline 2 & Education & 2 & 0.028 & 0.002 & 0.002 & 0.006 & 0.038 & 0.010 \\
\hline 3 & Healthcare & 6 & 0.015 & 0.005 & 0.004 & 0.003 & 0.027 & 0.012 \\
\hline 4 & Tourism & 3 & 0.013 & 0.005 & 0.004 & 0.005 & 0.026 & 0.013 \\
\hline 5 & Palm Oil & 7 & 0.008 & 0.005 & 0.007 & 0.004 & 0.025 & 0.016 \\
\hline 6 & $\begin{array}{l}\text { Wholesale and } \\
\text { Retail }\end{array}$ & 4 & 0.009 & 0.003 & 0.002 & 0.001 & 0.015 & 0.006 \\
\hline 7 & Others & 12 & 0.006 & 0.003 & 0.003 & 0.002 & 0.014 & 0.008 \\
\hline 8 & $\begin{array}{l}\text { Business } \\
\text { Services }\end{array}$ & 10 & 0.008 & 0.002 & 0.002 & 0.002 & 0.014 & 0.006 \\
\hline 9 & $\begin{array}{l}\text { Financial } \\
\text { Services }\end{array}$ & 11 & 0.003 & 0.002 & 0.003 & 0.005 & 0.013 & 0.010 \\
\hline 10 & $\begin{array}{l}\text { Communication } \\
\text { Content and } \\
\text { Infrastructure }\end{array}$ & 8 & 0.003 & 0.002 & 0.002 & 0.002 & 0.009 & 0.007 \\
\hline 11 & $\begin{array}{l}\text { Electronics and } \\
\text { Electrical }\end{array}$ & 5 & 0.002 & 0.002 & 0.002 & 0.001 & 0.007 & 0.005 \\
\hline 12 & $\begin{array}{l}\text { Oil, Gas and } \\
\text { Energy }\end{array}$ & 1 & 0.000 & 0.001 & 0.002 & 0.001 & 0.004 & 0.004 \\
\hline
\end{tabular}




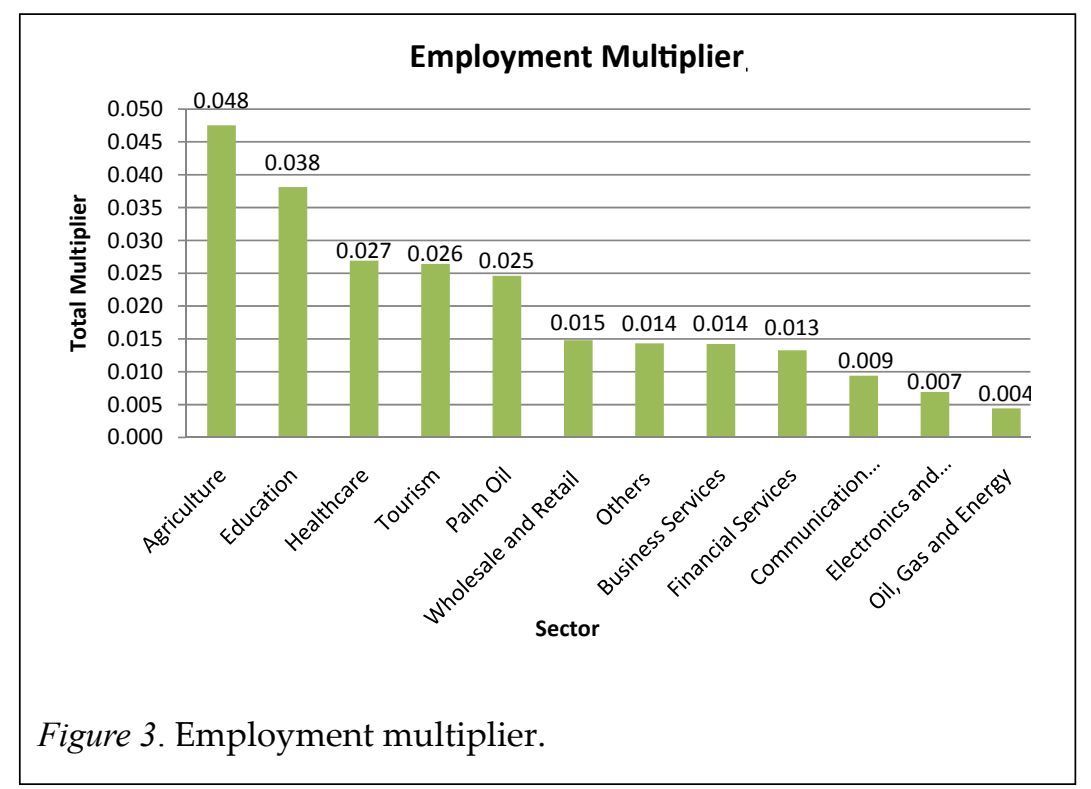

\section{Import Commodity Multiplier}

The import commodity multiplier is the amount of import commodity that will be generated in the Malaysian economy due to an increase of one Ringgit in the final demand. It directly causes a spillover of the Malaysian income to outside the Malaysian economy. A high import multiplier will affect the country's internal economic growth. Nevertheless, if our total export value is more than our total import value, it implies that we are earning extra revenue for our country. The analysis gives a total import multiplier that ranges from 0.196 to 0.662 , while the flow-on effect multiplier ranges from 0.142 to 0.267 .

The electronics and electrical sector has the highest total import multiplier compared to other sectors. Then, the second highest is Greater KL/Klang/others followed by the healthcare sector. All these sectors depend on the import of raw materials from overseas. At the other extreme, the communication content and infrastructure sector has the lowest import multiplier among the NKEA sectors.

Those sectors with high total import multipliers will cause a spillover of our hard currency out of this country. This hard currency will no longer circulate in the system, thus affecting the Malaysian economic growth. We should avoid importing goods from outside to help accelerate the economic growth of the country. 
IJMS 18 (Special Issue), 34-58 (2011)

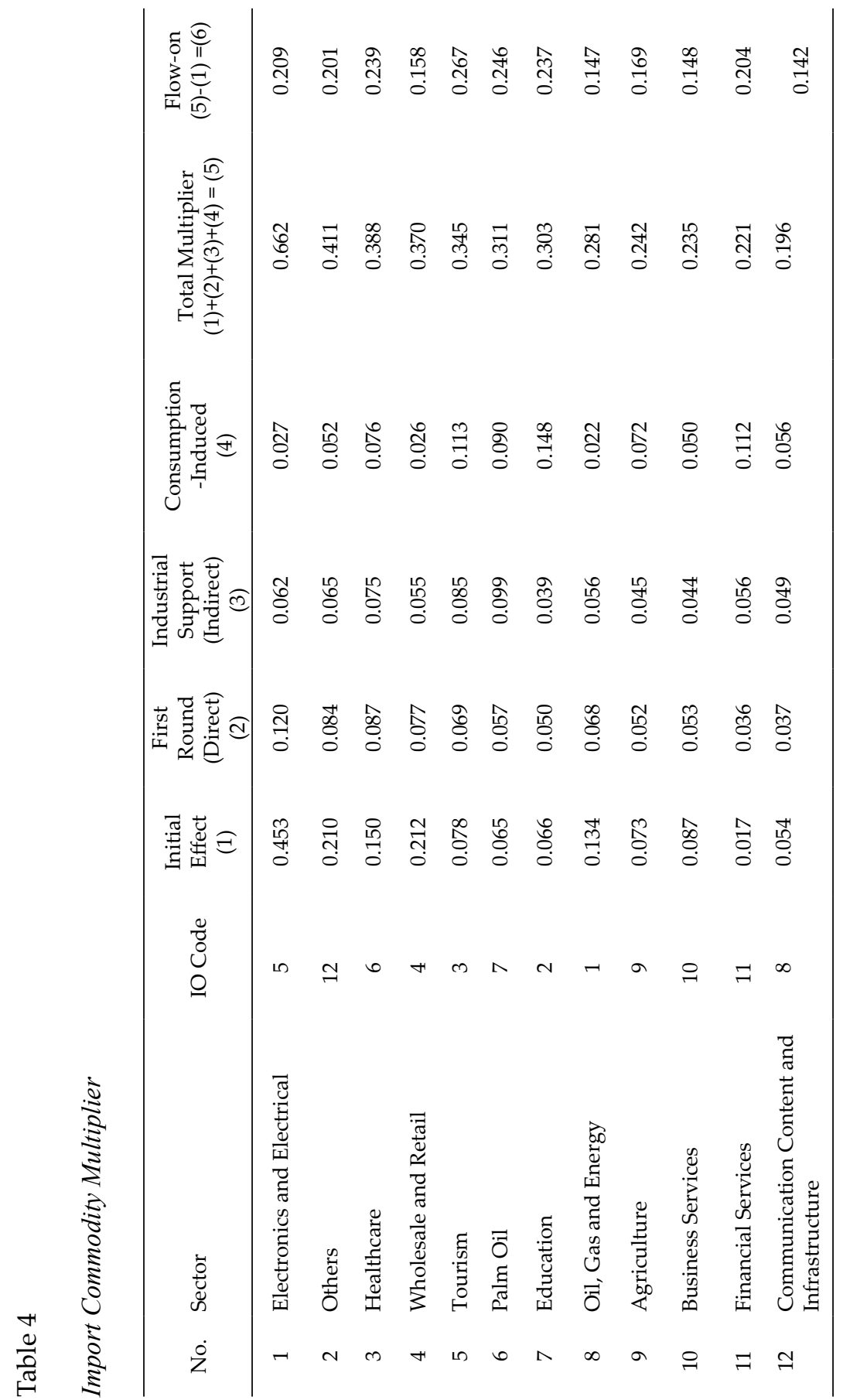




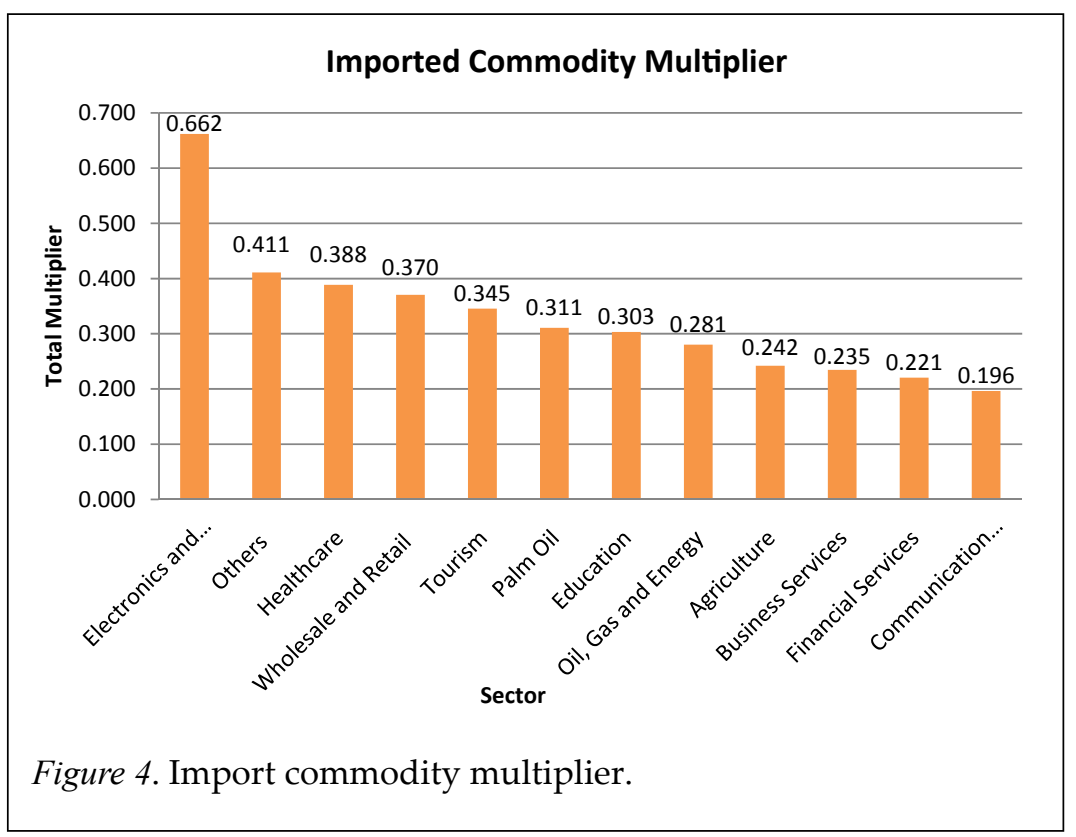

\section{Value-Added Multiplier}

Based on Table 5, the total value-added multiplier ranges from 0.415 to 1.137 , while the flow-on multiplier ranges from 0.267 to 0.690 . The education sector is the highest total value-added multiplier among the NKEA sectors. The following sectors are financial services and tourism. The development of these sectors is important in order to increase wealth for the country. The lowest value-added multiplier is the electronic and electrical sector. This sector can also increase wealth in the Malaysian economy, but at a slower pace.

In general, all of the NKEA sectors could generate economic activities for the Malaysian economy and creat wealth for the nation. Hence, Malaysia will become a high income-advanced nation with inclusiveness and sustainability by 2020 . 
IJMS 18 (Special Issue), 34-58 (2011)

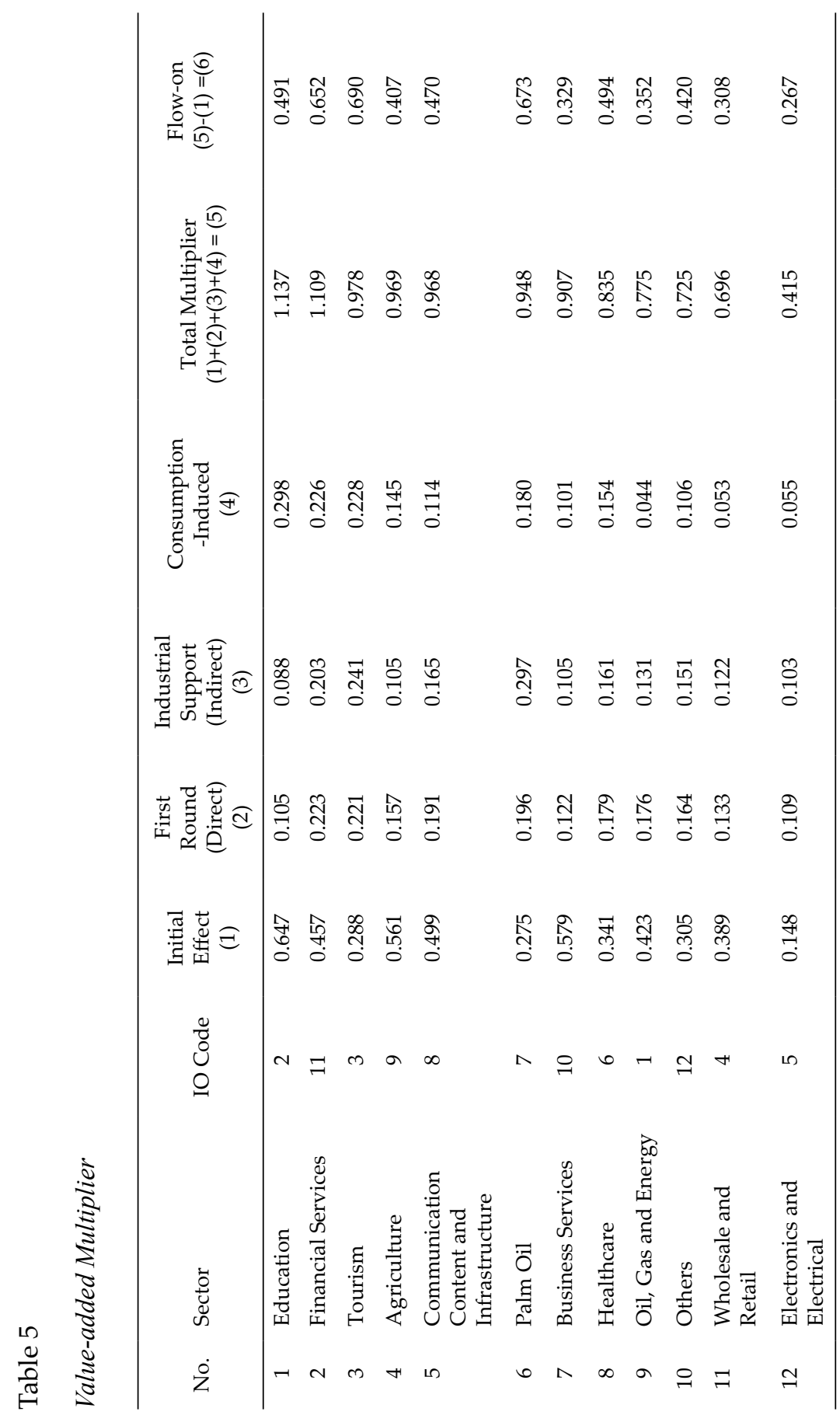




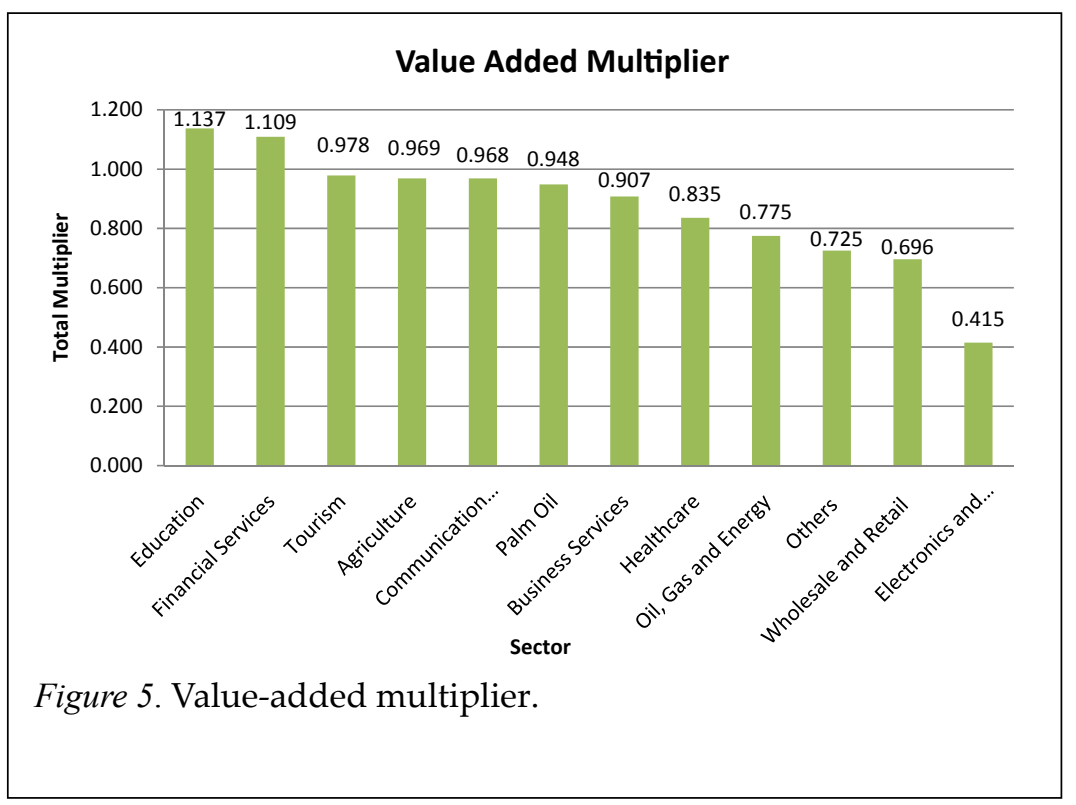

\section{Import Taxes Multiplier}

Import taxes are taxes that are imposed on commodities imported into the country. The taxes collected are revenue to the government. The analysis shows that the total import taxes multiplier ranges from 0.002 to 0.007 while the flow-on multiplier ranges from 0.002 to 0.004 .

According to Table 6, oil, gas and energy give the highest Malaysian commodity import taxes multiplier, followed by Greater KL/Klang/ others and financial services. At the other extreme, the government imposes less tax on the agriculture and the electronics and electrical sectors in order to expand and promote the local industries to increase local production for the country.

These import taxes multipliers are very important for two reasons. Firstly, they can be used as an instrument to protect our local industries and secondly we can use these multipliers to compute the government is revenue earned from the imported goods. The former is more important because we need to protect our local industries in order to create employment and income for the country. 
IJMS 18 (Special Issue), 34-58 (2011)

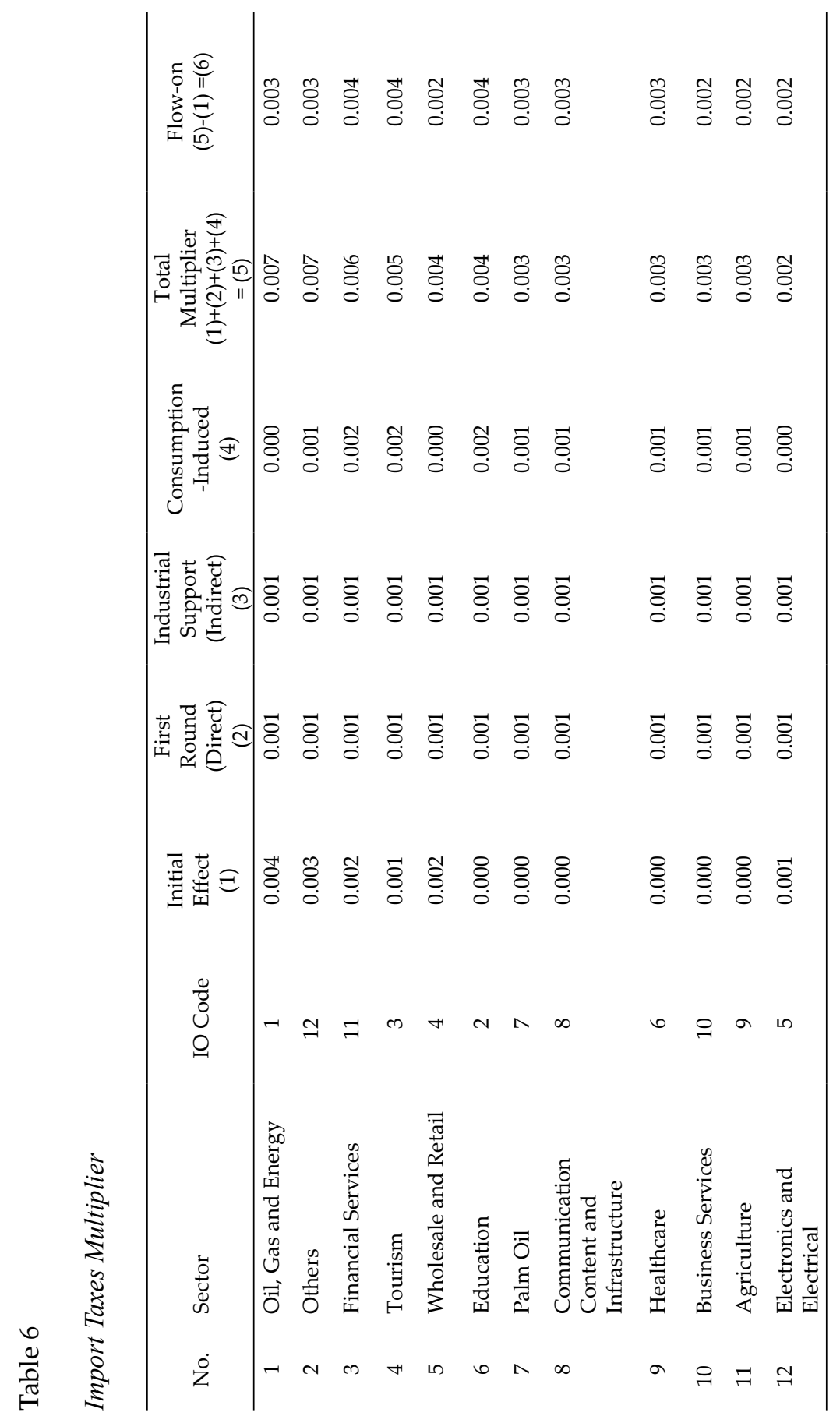




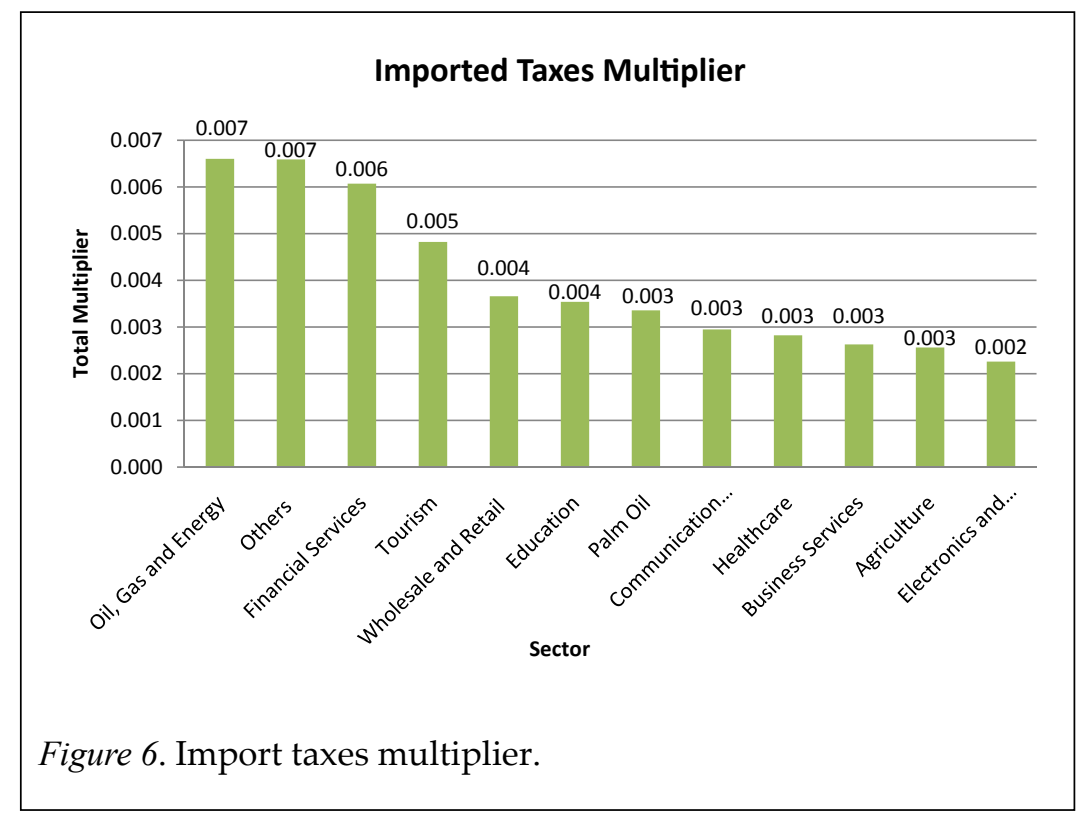

\section{Domestic Taxes Multiplier}

Domestic taxes are taxes imposed by the government on domestically produced commodities in the country. It is also the revenue for the government. The total domestic taxes multiplier ranges from 0.005 to 0.018 , while the flow-on ranges from 0.004 to 0.011 .

Based on the analyses, tourism is the most heavily taxed sector. The government collects tax from the tourism sector at the rate of 0.018 cent for every one Ringgit increase in the final demand. This is followed by Greater KL/Klang/other and palm oil sectors. The lowest domestic tax is the electronic and electrical sector.

The commodity domestic taxes multipliers also have dual purposes in the Malaysian economy. Firstly, taxes imposed can increase the competitiveness of the sectors. Secondly, the planner can estimate the government is revenue for the country. 
IJMS 18 (Special Issue), 34-58 (2011)

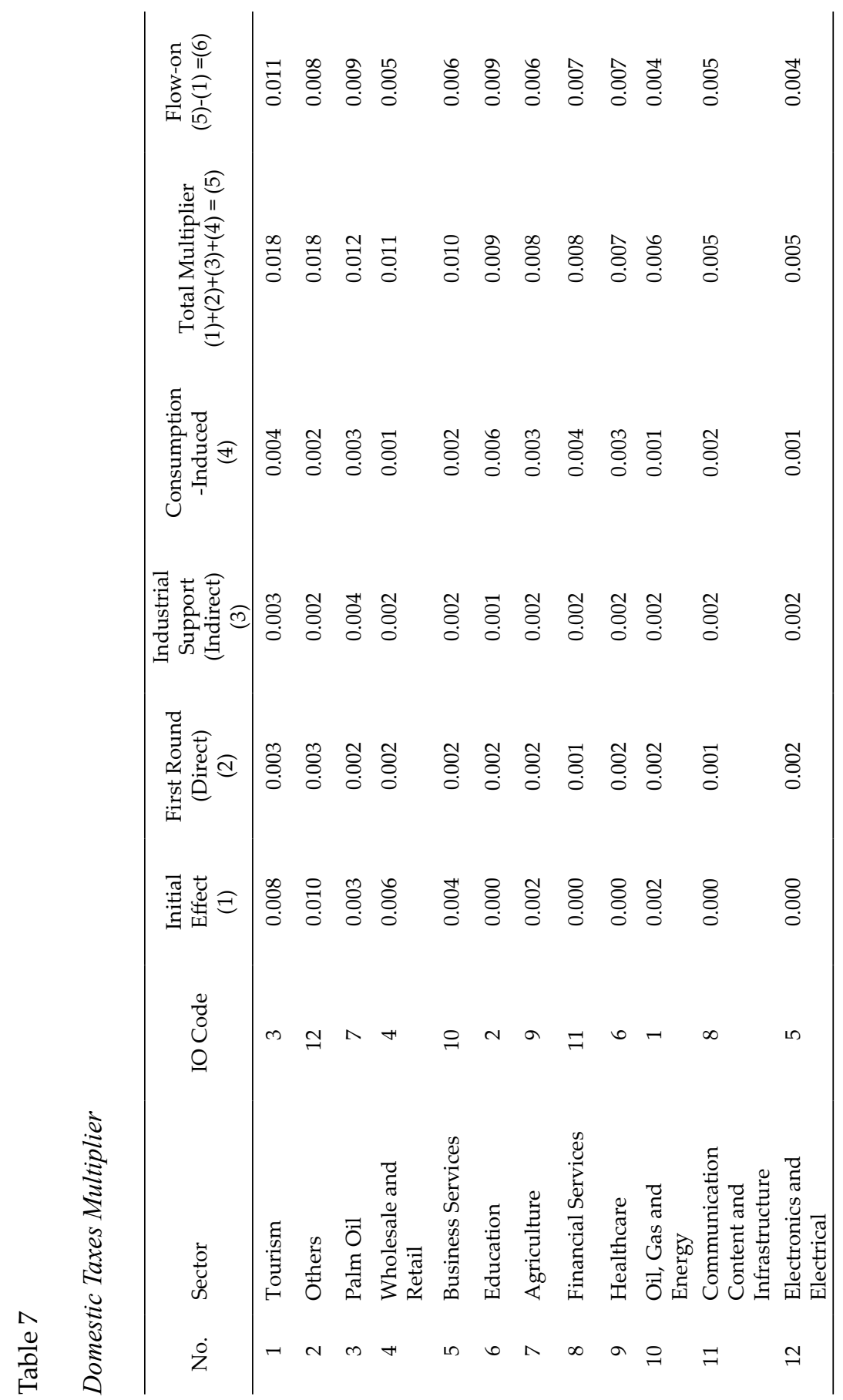




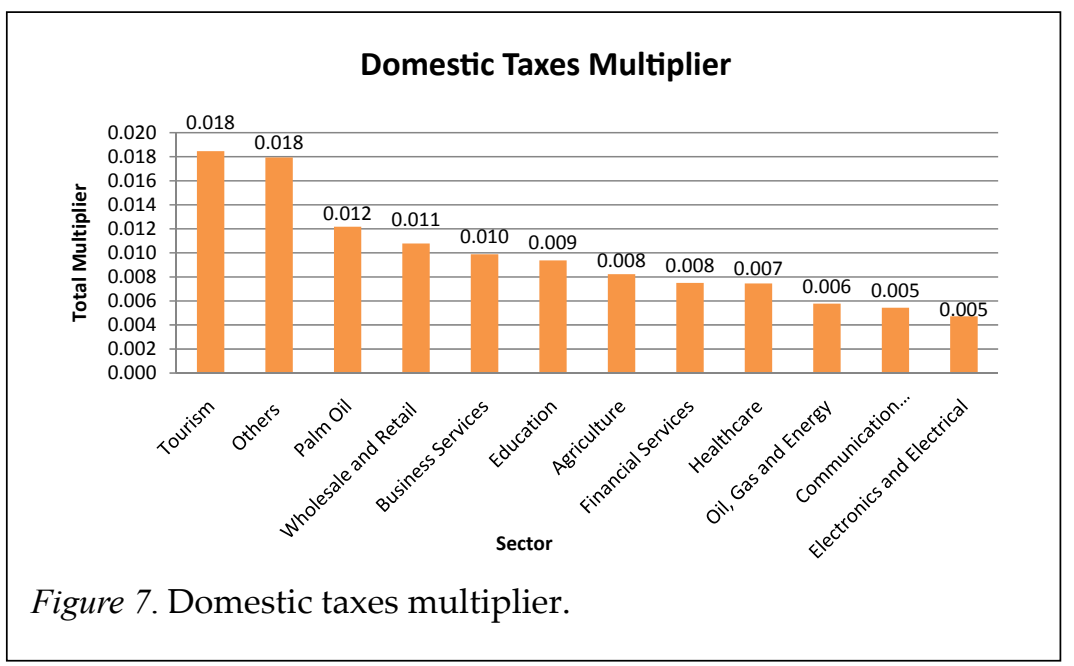

\section{Summary of Productive Sectors to be Developed}

Seven types of multipliers are computed in this analysis by using the IO Table 2005 data. All of the 12 NKEA sectors have been ranked from high to low values of the total multipliers and from value 1 to 10 . A sector will be given a score of 1 mark if it falls within 1 to 10 ranking for all the seven types of multipliers, with the exception of the import commodity multiplier, since it is good for the country if those sectors import fewer goods.

Six of the NKEA sectors had high scores of 7 marks, one sector had 6 marks, two sectors had 5 marks, two sectors had 4 marks and one sector had 2 marks.The education, tourism, healthcare, palm oil, business services and greater KL/Klang/others sectors were the top six NKEA sectors with the potential to be further developed in Malaysia. These sectors have all the seven outstanding total multipliers computed in the analysis. If the government wishes to boost the Malaysian economic sector for growth, these are the appropriate sectors for development.

The next line to be further developed are the agriculture, financial services, oil, gas and energy, communication content and infrastructure, wholesale and retail, and electronics and electrical. These sectors have less than six outstanding total multipliers out of seven which were computed in this analysis. 
IJMS 18 (Special Issue), 34-58 (2011)

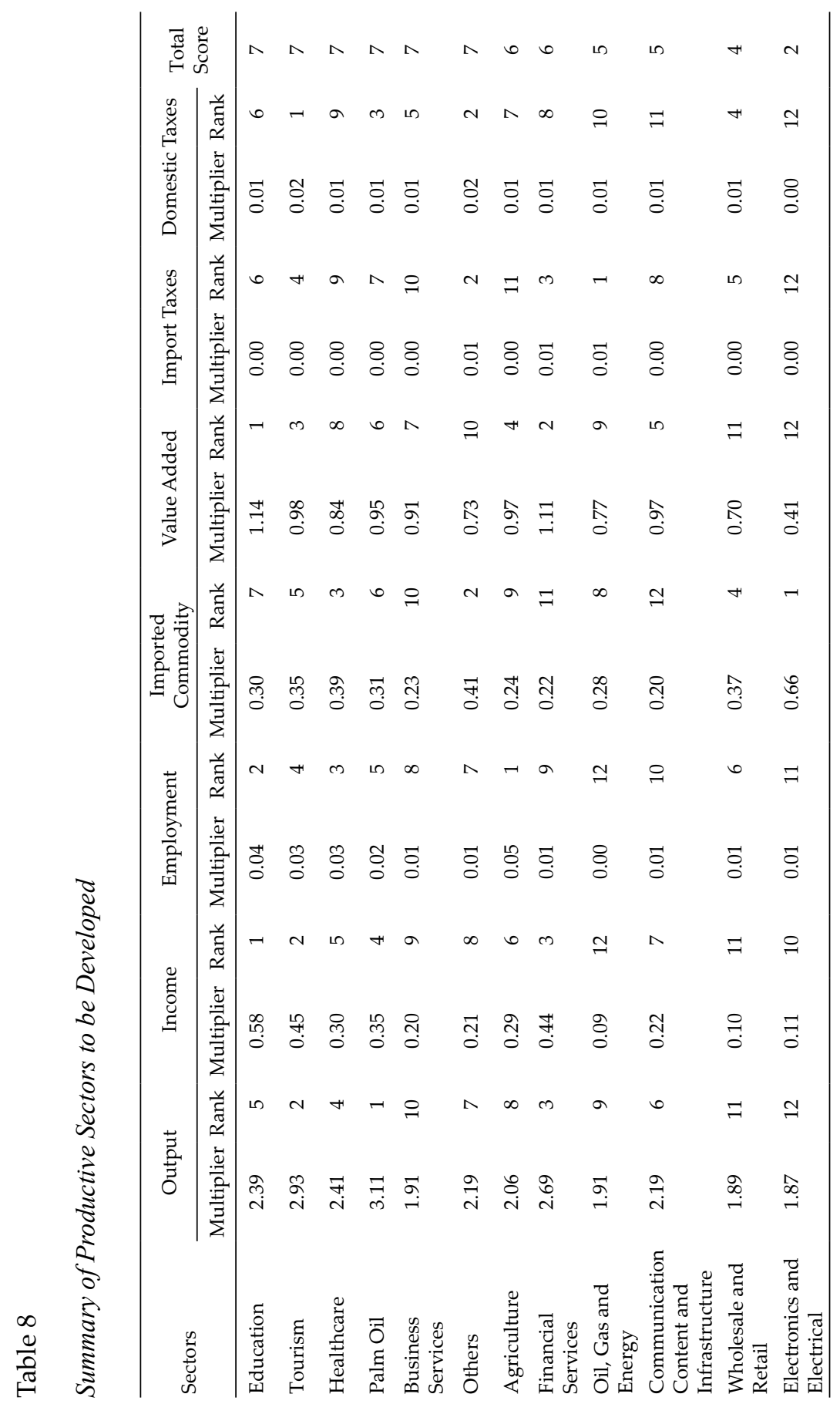




\section{Summary and Conclusion}

The main objective of this study is to provide an analysis of the multiplier impact on the Malaysian economy for 12 NKEA sectors. An overview of the structure and purposes of IO multipliers is provided in the Malaysian IO Table 2005. The computation of the complete IO multipliers includes total output, income, employment, import commodity, value-added, commodity import taxes and commodity domestic taxes multipliers for the NKEA sectors. A large multiplier shows that the industry sector has key status in the national economy. Based on this, we should give it priority in development.

Among the 12 NKEA sectors, education, tourism, healthcare, palm oil, business services and greater KL/Klang/others sectors have great potential for further development and are expected to give a high impact on the Malaysian economy. Hence, we can achieve the main goals of the NEM, which is Malaysia will become a high incomeadvanced nation with inclusiveness and sustainability by 2020 . In striving to achieve those goals, we cannot take the shortcut of pumppriming with wealth from natural resources, which is not sustainable.

The agriculture, financial services, oil, gas and energy, communication content and infrastructure, wholesale and retail, and electronics and electrical sectors are also capable of generating economic activities for the country, but have a slightly less impact on the Malaysian economy. However, we should not neglect them totally because they have other roles to play in the overall Malaysian economy.

\section{References}

Ahmad F. P., \& Alias R. (2007). Agriculture economic multiplier impact on the Malaysian economy: An input-output analysis. In Fatimah Mohamed Arshad, Nik Mustapha R. Abdullah, Amin Mahir Abdullah \& Bisant Kaur (Eds.), 50 years of Malaysian agriculture: Transformational issues, challenges and direction (pp. 442-473). Penerbit: UPM Press.

Aruna, P. B., Cubbage, F., Lee, K. J., \& Redmond, C. (1997). Regional economic contributors of the forest-based industries in the south. Forest Products Journal, 47, 35-45.

Christina, D., \& David, H. (2007). The macroeconomic effects on tax changes: Estimates based on a new measure of fiscal shocks. Retrieved from http://elsa.berkeley.edu/ 
IJMS 18 (Special Issue), 34-58 (2011)

David, K., Greg, A., \& MIG. (2007). A tool for modeling the economic impacts of regional biomass feedstock production: Input-output analysis. Retrieved from http://nesungrant.cornell.edu/

Dayton, O. (2009). Wright-Patterson air force based, economic impact analysis. Retrieved from http://www.wpafb.af.mil/

Department of Statistics Malaysia. (2010). Input-output tables Malaysia 2005.

Hugh, B., Ralph, T., \& James, W. (1982). An input-output analysis of Maine's fisheries. Retrieved from http://spo.nmfs.noaa.gov/

Miller, R. E., \& Blair, P. D. (1984). Input-output analysis: Foundations and extensions. New Jersey: Prentice-Hall.

National Economic Advisory Council. (2010). New economic model for Malaysia concluding part.

PEMANDU, Jabatan Perdana Menteri. (2010). Economic transformation programme: A roadmap for Malaysia.

Zakariah A. R., \& Soon J. J. (2002). Linkages and imports of Malaysia, 1978-1987: An input-output approach. 